\title{
Constructing a seasonal carbon balance for a forest ecosystem
}

\author{
Wendell P. Cropper, Jr, Henry L. Gholz \\ Department of Forestry, University of Florida, Gainesville, Florida 32611, USA
}

\begin{abstract}
Process based models of carbon dynamics in temperate forest ecosystems are often limited by inadequate data and/or model structures dealing with whole canopy physiology of mature trees, carbon allocation below-ground, and phenology and control of growth processes (carbon allocation). However, forest simulation models are useful tools for scaling up and integrating diverse field measurements, and evaluating complex hypotheses. As an example of this approach, we compared the pattern of carbon exchange of a pine forest in north Florida (USA) with the tropospheric $\mathrm{CO}_{2}$ concentration (measured at Mauna Loa, Hawaii, USA) over 2 yr. Daily ecosystem carbon gain and loss were largely in phase. Seasonal net ecosystem fluxes were smaller than observed for forests at higher latitudes and were poorly correlated with deviations in atmospheric carbon dioxide concentrations.
\end{abstract}

\section{INTRODUCTION}

In order to properly assess the potential impacts of climate change and other perturbations on forests, it is necessary to understand the dynamics of carbon, nutrient and water cycles in these ecosystems. Although numerous data are available on forest standing crops and expected growth rates (yield tables) for a wide variety of temperate forest ecosystems, relatively few mature forests have been adequately described at the process level. A focus at this level is necessary to deal with questions of physiological responses of trees and potential interactions among climate change, increased atmospheric $\mathrm{CO}_{2}$, pollution, and management strategies.

Mechanistic simulation models are an obvious tool for assessing dynamic responses of forests to perturbation scenarios. Simulation models are also useful for scaling up from the cuvette level, for rigorously evaluating the consequences of mathematically formulated hypotheses, and as a tool for understanding the modeled system and identifying data needs. The weakest use of simulation models is for predicting perturbation responses. Models by definition are homomorphisms, that is, they cannot include the entire non-linear response surface of the modeled system (Patten 1971). It should also be noted, however, that it is logistically impossible to carry out a series of factorial experiments designed to elucidate the ecosystem response surface to all potential, or even likely, combinations of relevant environmental variables.

Some of the critical research needs for improving our ability to predict forest dynamics include detailed and practical canopy models, measurements of physiological responses in mature trees, accurate estimates of below-ground production, and a better understanding of within-tree carbon allocation and controls on phenology. There are few examples of forest stands with studies that can satisfy more than one of these research needs. During the past $15 \mathrm{yr}$, we (with $\mathrm{K}$. C. Ewel of the University of Florida, R. O. Teskey of the University of Georgia, and others) have attempted to address these issues with an integrated program of field research and modeling of slash pine Pinus elliottii var, elliottii plantation ecosystems in Florida, USA.

Our objective in this paper is to present a seasonal carbon balance for a Florida slash pine ecosystem as an example of using a model to integrate diverse measurements of carbon standing crops and fluxes, and to describe net ecosystem carbon exchange with the atmosphere. Although the simulated forest represents a particular location in north-central Florida, we believe that the seasonal dynamics are broadly representative of southern pine forests. Loblolly Pinus taeda 




Fig. 1. Diagram of the slash pine model. $D E C=$ decomposition; $G R=$ growth respiration; Mort $=$ mortality; $M R=$ maintenance respiration; $\mathrm{NCA}=$ net canopy assimilation; Temp = temperature , and TMR = total pine maintenance respiration. The dashed lines represent summed variables from several compartments. (From Cropper \& Gholz 1993)

and slash pines have similar physiology (R. O. Teskey \& D. Whitehead unpubl.), and the seasonal foliage dynamics, with 2 needle age classes, are also similar (Dougherty et al. 1990, Gholz et al. 1991).

\section{SIMULATION OF CARBON DYNAMICS IN SLASH PINE FORESTS}

Our field data were obtained from forest stands at $29^{\circ} 44^{\prime} \mathrm{N}, 82^{\circ} 9^{\prime} 30^{\prime \prime} \mathrm{W}$, in north-central Florida, where the mean annual temperature is $21.7^{\circ} \mathrm{C}$ and the mean annual precipitation is $1320 \mathrm{~mm}$. The vegetation was dominated by indigenous open-pollinated slash pine planted at a density of $1190 \pm 118 \mathrm{ha}^{-1}$ after clear- felling of the former forest stand in 1965. Site preparation was minimal, and no herbicides or fertilizers were applied to the developing stand. The understory consisted of native species dominated by 2 evergreen shrubs, Serenoa repens and Ilex glabra. Soils were sandy and poorly drained Spodosols (Gaston et al. 1990).

Data on net assimilation ( $R$, O Teskey, H. L. Gholz \& W. P. Cropper unpubl.), growth and maintenance respiration of all tissues of the trees including roots (Cropper \& Gholz 1991, 1993), canopy leaf area, stand biomass, and litterfall dynamics (Gholz et al. 1991), and the internal tree storage patterns of starch and soluble sugars (Gholz \& Cropper 1991) were obtained between February 1987 and January 1989 through extensive field sampling. Understory seasonal leaf area and net production rates were also measured (D. Guerin \& H. L. Gholz unpubl.). Finally, previously derived values for soil organic matter decay (Ewel et al. $1987 \mathrm{a}, \mathrm{b}$ ) and fine root turnover (Gholz et al. 1986) were used after verification through partitioning of soil $\mathrm{CO}_{2}$ evolution and the direct measurement of fine root respiration (Cropper \& Gholz 1991). Results of these measurements were integrated using the SPM (slash pine model; Cropper \& Gholz 1993).

The SPM (Fig. 1) simulates hourly assimilation and maintenance respiration driven by locally measured environmental data. Growth, decomposition, litterfall, soil $\mathrm{CO}_{2}$ evolution, and labile carbon pool dynamics are simulated on a daily time step. The state variables include slash pine new and old foliage, branches, stems, coarse roots, fine roots in the litter layer, fine roots in the mineral soil, needle litter, dead fine roots, soil organic matter, and the labile carbon pool (sugars and starch).

Proper simulation of net canopy assimilation in flatwoods slash pine plantations depends primarily on adequate representation of the canopy light environment (R. O. Teskey, H. L. Gholz \& W. P. Cropper unpubl.\}. The assumptions of a simple Beer-Lambert light extinction model are not appropriate for the slash pine canopy. The SPM uses a 9-vertical-layer canopy model with a correction for relative gap frequency (Sinclair \& Knoerr 1982) to account for 
canopy patchiness. The equation used to simulate the vertical distribution of light within the slash pine canopy is:

$$
\operatorname{PAR}_{x}=\mathrm{PAR}_{0} \cdot \exp \left(-k F_{x} \lambda / \mathrm{SE}\right)
$$

where PAR is the PAR (photosynthetically active radiation) incident at the midpoint of canopy layer $x$, $\mathrm{PAR}_{0}$ is the above-canopy PAR, $k$ is a constant, $F_{x}$ is the cumulative projected LAI (leaf area index) above the midpoint of canopy layer $x, \lambda$ is the relative canopy gap frequency, and SE is the sine of the solar elevation angle. In addition, the foliage age class dynamics (Gholz et al. 1991) lead to significant seasonal variation in foliage biomass (Fig. 2). An assumption that mature 'closed canopy' forests exhibit constant foliage biomass may lead to serious errors in estimating the annual magnitude and seasonal patterns of canopy physiological processes

Estimation of below-ground productivity, through soil coring or observational techniques, is complicated by spatial heterogeneity and time consuming efforts to sort and/or classify roots according to species, viability, and size. Estimates of fine root production may vary widely depending on the sampling intensity, frequency, and statistical methods used. If only the few statistically significant differences in repeated samples of fine root biomass are used to calculate production and mortality (e.g. Santantonio \& Grace 1987), estimates will be lower than those that sum all differences (Singh et al, 1984). Soil $\mathrm{CO}_{2}$ evolution can be (but rarely is) used to estimate below-ground carbon allocation (Raich \& Nadelhoffer 1989) and to test the consistency of independent estimates of root turnover, respi-



Fig. 2. Simulated seasonal slash pine foliage biomass dynamics for $<1 \mathrm{yr}$ old (new), $>1 \mathrm{yr}$ ald (old) and total (sum of old and new) ration and decomposition (Ewel et al. 1987b. Cropper \& Gholz 1993).

Although a goal of 'mechanistic' simulation models is to describe biological phenomena from theoretically based principles, modeling growth phenology and/or carbon allocation often uses empirical elements. For example, the TREGRO model (Weinstein et al. 1991) simulates carbon allocation based on a balance of carbon and nutrient gradients along the plant axis, but empirically constrains phenology. SPM simulations (Cropper \& Gholz unpubl.) indicate that the increased carbon allocation to foliage mass following fertilization could be explained by a small (5\%) decrease in carbon allocation to fine roots or a $15 \%$ increase in assimilation rates. Field measurements indicate that assimilation and respiration rates did not respond to enhanced nutrition, and variation in fine root biomass data was too great to detect a $5 \%$ magnitude response (Cropper \& Gholz 1991, R. O. Teskey, H. L. Gholz \& W. P. Cropper unpubl.). A more complete understanding of the mechanisms controlling the timing and magnitude of carbon allocation is required for the construction of more useful models. In this paper we will confine our discussion to the carbon dynamics of unfertilized stands only.

\section{ANNUAL NET ECOSYSTEM CARBON STORAGE}

We estimated net ecosystem carbon storage by subtracting simulated maintenance and growth respiration and decomposition from net canopy assimilation. Annual net storage of ecosystem carbon was estimated at $78 \mathrm{~g} \mathrm{~m}^{-2} \mathrm{yr}^{-i}$ in $1987-88$ and $139 \mathrm{~g} \mathrm{~m}^{-2}$ $\mathrm{yr}^{-1}$ in 1988-89. Annual rates of carbon exchange are highly dependent upon age of the tree stand in even-aged plantations (Gholz \& Fisher 1982); in this stand they were relatively low, because the understory and soil organic carbon pools were nearly in equilibrium and the stand was approaching its cultural rotation length of $25 \mathrm{yr}$ (mean above-ground net primary production was $461 \mathrm{~g} \mathrm{C} \mathrm{m}^{-2} \mathrm{yr}^{-1}$ from 1987-1989; Gholz et al. 1991).

The higher net carbon storage for the second year reflected a higher LAI and, as a result, higher net canopy assimilation. Annual releases of carbon from the ecosystem to the atmosphere (1988-89) were attributable in roughly similar amounts to microbial respiration in soil and litter (42\%) and to plant respiration $(58 \%)$. To determine the potential effects of a wider range in environmental conditions, $23 \mathrm{yr}$ of climate data from Gainesville, Florida, were also used to drive the model using constant initial biomass levels from 1988-89. The net carbon storage from these simulations ranged from 59 to 
$183 \mathrm{~g} \mathrm{~m}^{-2} \mathrm{yr}^{-1}$, indicating that the potential annual variation in carbon storage due to normal weather variation is greater than was experienced from 1987 to 1989

\section{SEASONAL PATTERNS OF ECOSYSTEM CARBON EXCHANGE}

Although the magnitude of the annual carbon balance is strongly affected by the age of the trees in these even-aged stands, there is no reason for its seasonality to be. Therefore, the seasonal pattern we observed should be broadly representative of the regionally dominant managed pine ecosystems in the southeastern U.S. on similar soils. The greatest contributor to seasonal fluctuations was net carbon gain by the tree canopy, which was affected both by seasonal changes in light and temperature and by a large seasonal change in LAI (Gholz et al. 1991). Seasonal fluctuations in root biomass and soil temperature were much lower, resulting in lower seasonal fluctuations in carbon release from roots and decomposition of soil organic matter.

The seasonal amplitude of atmospheric $\mathrm{CO}_{2}$ is attributable to the pattern of $\mathrm{CO}_{2}$ exchange with terrestrial ecosystems (Hall et al. 1975, Woodwell 1983, Keeling \& Shertz 1992). The seasonal atmospheric $\mathrm{CO}_{2}$ signal is much greater in the Northern Hemisphere than in the Southern Hemisphere, primarily because of the much larger land area but also due to the greater extent of deciduous forest (Pearman \& Hyson 1981). In addition, seasonal fluctuations in the Northern Hemisphere have been increasing, suggesting an increasingly dominant role of northern temperate and boreal forests in the global carbon cycle, perhaps due to a $\mathrm{CO}_{2}$ fertilization effect (Brown et al. 1981, Pearman \& Hyson 1981, Lamarche et al. 1984, Kienast \& Luxmoore 1988, Eamus \& Jarvis 1989 ) or to increased respiration associated with increasing winter temperatures at higher latitudes (Houghton 1987a). Seasonal atmospheric fluctuations also decrease toward the equator, possibly due to a very long growing season in warm regions and dilution effects from $\mathrm{CO}_{2}$ sources in the Southern Hemisphere (Houghton 1987b). However, in spite of their potentially important role in controlling seasonal atmospheric $\mathrm{CO}_{2}$ fluctuations, there are few actual observations of seasonal atmospheric $\mathrm{CO}_{2}$ exchange for whole forest ecosystems (Eamus \& Jarvis 1989).
The annual simulated range in daily carbon exchange for the slash pine ecosystem was -1.5 to $+1.9 \mathrm{~g}$ $\mathrm{m}^{-2} \mathrm{~d}^{-1}$ for $1987-88$ and -1.7 to +1.4 for $1988-89$. In contrast, Houghton (1987b) derived a carbon budget for a deciduous hardwood forest at Brookhaven. New York. Daily carbon exchange at Brookhaven ranged over a year from -3.0 to $+3.5 \mathrm{~g} \mathrm{~m}^{-2} \mathrm{~d}^{-1}$, reflecting a larger seasonal fluctuation in air temperature and radiation than in Florida and the lack of significant carbon gain during the leafless period in winter.

The lower seasonality in Florida supports the argument that the reduced seasonality in atmospheric $\mathrm{CO}_{2}$ concentrations observed at lower latitudes is in fact due to lower ecosystem exchange rates and not to a damping effect of the mixed Northern and Southern Hemisphere signals that are $180^{\circ}$ out of phase (Gillette $\&$ Box 1986). In support of this conclusion, the seasonality of the Florida ecosystem carbon balances does not match well with the Northern Hemisphere atmospheric signal recorded at Mauna Loa (Fig. 3). The closest agreement with the atmospheric pattern is during the autumn of both years. At this time, decreasing light and peak needle shedding reduced ecosystem net carbon gain at the same time that atmospheric concentrations were increasing. This indicates that the Florida pine ecosystem was in synchrony with other Northern Hemisphere ecosystems at this time of the year.

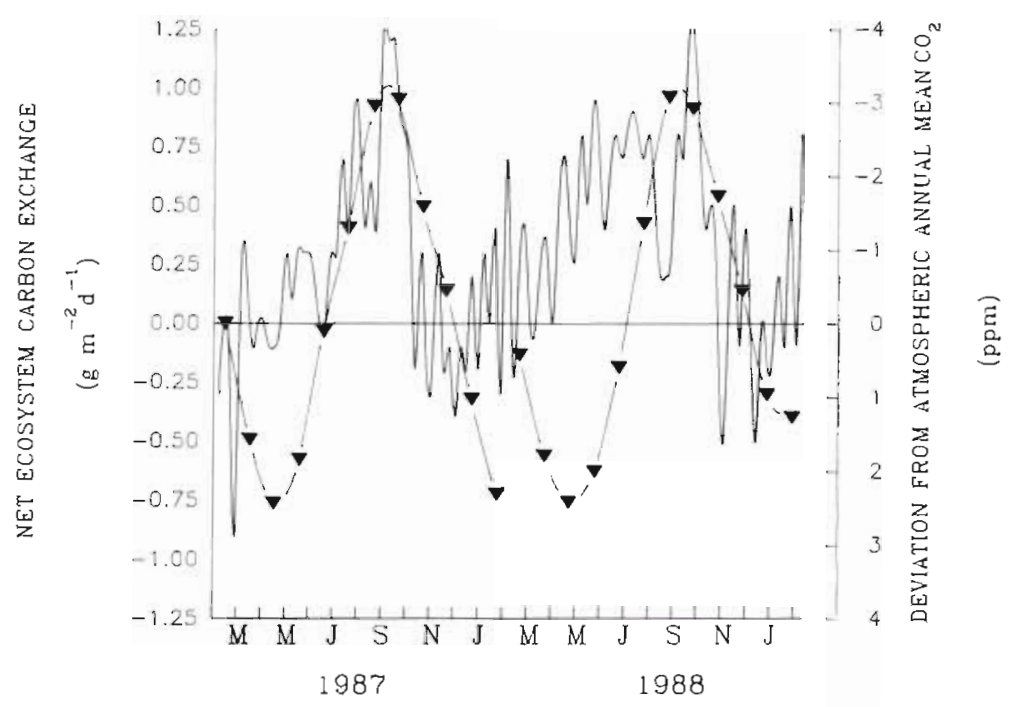

Fig. 3. (-) Simulated $7 \mathrm{~d}$ mean net $\mathrm{C}$ balances for the pine ecosystem [(net canopy assimilation) - (respiration and decomposition) ), and ( $\mathbf{\nabla}-\mathbf{v})$ deviations of atmospheric $\mathrm{CO}_{2}$ concentrations at Mauna Loa from annual means for March 1987 to February 1988 and March 1988 to February 1989 (C. D. Keeling unpubl. data, obtained through the Carbon Dioxide Information Analysis Center, Oak Ridge National Laboratory, IN). Note that positive deviations of the atmospheric concentrations indicate a net accumulation of $\mathrm{C}$ in the atmosphere. The discontinuity between Years 1 and 2 (at March 1988 ) in the $\mathrm{CO}_{2}$ deviation curve is due to the secular trend of increasing atmospheric concentrations 
The highest rates of net carbon gain were also observed in early autumn, just prior to peak needlefall, when new foliage was fully expanded and temperatures were moderate. The greatest discrepancies between the atmospheric and ecosystem patterns occurred in late winter and spring, especially in 1988-89, when the Florida ecosystem showed much greater carbon gain than the atmospheric signal indicated was characteristic of the hemisphere as a whole. Evergreen vegetation and mild temperatures under mostly clear skies in Florida result in virtually flat winter patterns, with low oscillations around a zero balance. Water stress had no significant effect on carbon gain or losses in this ecosystem, where soil water tables occur near enough to the surface all year for access by deep roots.

Carbon gains were seasonally synchronous with carbon losses through respiration and decomposition in both years (Fig. 4). This leads to the relatively low seasonality in the ecosystem balance and further supports Houghton's (1987b) conclusion that lowlatitude forests play a less important role in regulating the magnitude of atmospheric fluctuations. Because the net annual carbon balances were different in the 2 years we observed and appear to fluctuate even more, given the variability observed in the 23 yr climate simulations, forest carbon balances appear to be highly sensitive to annual differences in weather in spite of a large storage of carbon in perennial structures.

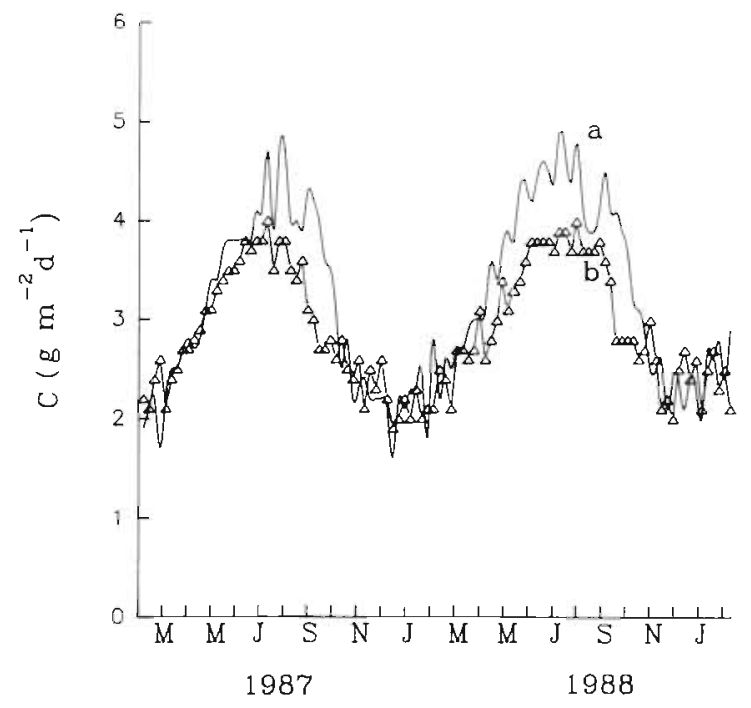

Fig. 4. (a) Simulated weekly average mean daily net slash pine canopy $C$ gain, and (b) total ecosystem $C$ release through plant respiration and decomposition
Acknowledgements. Funding for this research was provided by Environmental Protection Agency cooperative agreement CR817538 from the EPA Global Change Research program and from National Science Foundation grant No. BSR 8106678 from the Ecosystem Studies Program. The stands for this research were used with the permission of the JeffersonSmurfit Company. This is Journal Series Number R-02994 of the Institute of Food and Agricultural Sciences, University of Florida, Gainesville, Florida 32611

\section{LITERATURE CITED}

Brown, S., Gertner, G., Lugo, A. E., Novak, J. (1981). Carbon dioxide dynamics in the biosphere. In: Mitsch, W. J., Bosserman, R. W., Klopatek, J. M. (eds.) Energy and ecological modelling. Elsevier, Amsterdam, p. 19-28

Cropper, W. P. Jr, Gholz, H. L. (1991). In situ needle and fine root respiration in mature slash pine trees. Can. J. For. Res. 21: 1589-1595

Cropper, W. P. Jr, Gholz, H. L. (1993), Simulation of the carbon dynamics of a Florida slash pine plantation. Ecol. Modelling 66: 231-249

Dougherty, P. M., Oker-Blom, P., Hennessey, T. C., Witter, R. E., Teskey, R. O. (1990). An approach to modelling the effects of climate and phenology on the leaf biomass $d y$ namics of a loblolly pine stand. Silva Carelica 15: 133-143

Eamus, D., Jarvis, P. G. (1989). The direct effects of increases in the global atmospheric $\mathrm{CO}_{2}$ concentration on natural and commercial temperate trees and forests. Adv. ecol. Res. 19: 1-55

Ewel, K. C., Cropper, W. P. Jr, Gholz, H. L. (1987a). Soil $\mathrm{CO}_{2}$ evolution in Florida slash pine plantations. I. Changes through time. Can. J. For. Res. 17: 325-329

Ewel, K. C., Cropper, W. P. Jr, Gholz, H. L. (1987b). Soil $\mathrm{CO}_{2}$ evolution in Florida slash pine plantations. II. Importance of root respiration. Can. J. For. Res. 17: 330-333

Gaston, L., Nkedi-Kizza, P., Sawka, G., Rao, P. S. C. (1990). Spatial variability of morphological properties at a Florida flatwoods site. Soil Sci. Soc. Am. J. 54: 527-533

Gholz, H. L., Fisher, R. F. (1982). Organic matter production and distribution in slash pine (Pinus elliottil) plantations. Ecology 63: 1827-1839

Gholz, H. L., Hendry, L. C., Cropper, W. P. Jr (1986). Organic matter dynamics of fine roots in plantations of slash pine (Pinus elliottil) in north Florida. Can. J. For. Res. 16: 529-538

Gholz, H. L., Vogel, S. A., Cropper, W. P. Jr, McKelvey, K., Ewel, K. C., Teskey, R. O., Curran, P. J. (1991). Dynamics of canopy structure and light interception in Pinus elliottii stands of north Florida. Ecol. Monogr. 61: 33-51

Gholz, H. L., Cropper, W. P. Jr (1991). Carbohydrate dynamics in mature Pinus elliottii var elliottii trees. Can. J. For. Res. 21: $1742-1747$

Gillette, D. A., Box, E. O. (1986). Modeling seasonal changes of atmospheric carbon dioxide and carbon 13. J. geophys. Res. 91: $5287-5304$

Hall, C. A. S., Ekdahl, C. A., Wartenberg, D. E. (1975). A. fifteen year record of biotic metabolism in the Northern Hemisphere. Nature 255: 136-138

Houghton, R. A. (1987a). Biotic changes consistent with the increased seasonal amplitude of atmospheric $\mathrm{CO}_{2}$ concentrations. J. geophys. Res. 92: 4223-4230

Houghton, R. A. (1987b). Terrestrial metabolism and atmospheric $\mathrm{CO}_{2}$ concentrations. BioSci. 37: 672-678

Keeling, R. F., Shertz, S. R. (1992). Seasonal and interannual variations in atmospheric oxygen and implications for the global carbon cycle. Nature 358: 723-727 
Kienast, F., Luxmoore, R. J. (1988). Tree-ring analysis and conifer growth responses to increased atmospheric $\mathrm{CO}_{2}$ levels. Oecologia 76: 487-495

Lamarche, V. C. Jr, Graybill, D. A., Fritts, H. C., Rose, M. R (1984). Increasing atmospheric carbon dioxide: tree ring evidence for growth enhancement in natural vegetation. Science 225: 1019-1021

Patten, B. C. (1971). A primer for ecological modeling and simulation with analog and digital computers. In: Patten, B. C. (ed.) Systems analysis and simulation in ecology, Vol. 1. Academic Press, New York, p. 3-121

Pearman, G. I., Hyson, P. (1981). The annual variation of atmospheric $\mathrm{CO}_{2}$ concentration observed in the Northern Hemisphere. J. geophys. Res. 86: 9839-9843

Raich, J. W., Nadelhofter, K. J. (1989). Belowground carbon allocation in forest ecosystems: global trends. Ecology 70 : $1346-1354$
Santantonio, D., Grace, J. C. (1987). Estimating fine-root turnover from biomass and decomposition data: a compartment-flow model. Can. J. For. Res. 17: 900-908

Sinclair, T. R., Knoerr, K. R. (1982). Distribution of photosynthetically active radiation in the canopy of a loblolly pine plantation. J. appl. Ecol. 19: 183-191

Singh, J. S., Lauenroth, W. K., Hunt, H. W., Swift, D. M. (1984). Bias and random errors in estimators of net root production: a simulation approach. Ecology 65: 1760-1764

Weinstein, D. A., Beloin, R. M., Yanai, R. D. (1991). Modeling changes in red spruce carbon balance and allocation in response to interacting ozone and nutrient stresses. Tree Physiol. 9: 127-146

Woodwell, G. M. (1983). Biotic effects on the concentration of atmospheric carbon dioxide: a review and projection. In: Changing climate. Nat. Acad. Press. Washington, DC., p. $216-241$ 